\title{
DYNAMICS OF PHYSICAL AND BIOLOGICAL SYSTEMS OF THE PRINCE EDWARD ISLANDS IN A CHANGING CLIMATE
}

\author{
by I. J. Ansorge, J. V. Durgadoo and E. A. Pakhomov
}

(with four text-figures)

\begin{abstract}
Ansorge, I.J ., Durgadoo, J .V. \& Pakhomov, E.A. 2009 ( 11 :xii): Dynamics of physical and biological systems of the Prince Edward Islands in a changing climate. Papers and Proceedings of the Royal Society of Tasmania 143(2): 15-18.

https://doi.org/10.26749/rstpp.143.1.15 ISSN 008-4703. Oceanography Department, Marine Research Institute, University of Cape Town, Rondebosch 7701, South Africa (IJA*, JVD), Department of Earth and Ocean Sciences, University of British Columbia, Vancouver, V6T1Z4, Canada (EAP).*Author for correspondence. Email: Isabelle.ansorge@uct.ac.za
\end{abstract}

\begin{abstract}
Sub-Antarctic islands are classified as isolated, hostile, impoverished regions, in which the terrestrial and marine ecosystems are relatively simple and extremely sensitive to perturbations. They provide an ideal ecological laboratory for studying how organisms, ecological processes and ecosystems respond to a changing ocean climate in the Southern Ocean. These islands are characterised by large populations of top predators and subsequently any changes in the oceanographic frontal dynamics associated with the Antarctic Circumpolar Current, either in the vicinity of these islands or further afield, may have strong implications on their foraging behaviour. The relatively easy accessibility of the Prince Edward Islands from South Africa and their location between the main frontal systems bordering the Antarctic Circumpolar Current enable high-resolution synoptic field studies to be undertaken. Such studies have provided information on the impact changes in the large-scale ocean dynamics have on the local marine ecosystems.
\end{abstract}

Key Words: Prince Edward Islands, ocean variability, Sub-Antarctic Front.

\section{INTRODUCTION}

The oceanic thermohaline circulation, often referred to as the ocean's "conveyor belt", is a vital link in the global transport of heat from the tropics to higher latitudes. The physical structure of this circulation belt and its efficiency in regulating climate is substantially influenced by the nature of water mass exchange between ocean basins (Gordon 1986, Speich et al. 2001). The Southern Ocean is the name given to the oceanic region that surrounds the entire Antarctic continent. It comprises the southern extents of the Atlantic, Indian and Pacific oceans, with the Antarctic continent forming the southern boundary of the Southern Ocean, while the northern border is not physiographically fixed, but is usually considered to coincide with the geographic location of the Subtropical Convergence (Lutjeharms 1985). Dominating the flow of the Southern Ocean is the Antarctic Circumpolar Current (ACC), which, extending unbroken around Antarctica, is the primary means by which heat and salt are transferred between different ocean basins. The major part of the flow associated with this current is concentrated at a number of circumpolar fronts (fig. 1), which act as boundaries separating zones of uniform water masses. Although thesefronts are circumpolar they show a strong temporal variability in latitude between different oceanic sectors (Lutjeharms 1985).

Recent studies have shown that since the 1950s the ACC has strengthened and migrated southwards by $50-70 \mathrm{~km}$, resulting in an increase in global ocean temperatures in the upper $1000 \mathrm{~m}$ (Gille 2002). The most rapid warming appears to be concentrated along the Sub-Antarctic Front (SAF) and may be linked to the formation of Sub-Antarctic Mode Water (SAMW). SAMW is ventilated annually and therefore responds to rapidly changing atmospheric and oceanic conditions (McCartney 1982). Changes of these mid-depth temperatures may imply a net warming and consequently a reduction in the volume of cold circumpolar waters separating the ACC from the Antarctic continent.
Furthermore, recent ocean models have indicated that a southern shift and intensification in the prevailing westerly wind field driving the ACC may result in an increase in the upwelling of deep water masses (Oke \& England 2004). Such changes could potentially influence the volume and stability of the cryosphere and may have important consequences on the uptake of anthropogenic $\mathrm{CO}_{2}$ and hence "the ability of the world ocean to mitigate the impact of global warming" (Fyfe \& Saenko 2006 p. 5).

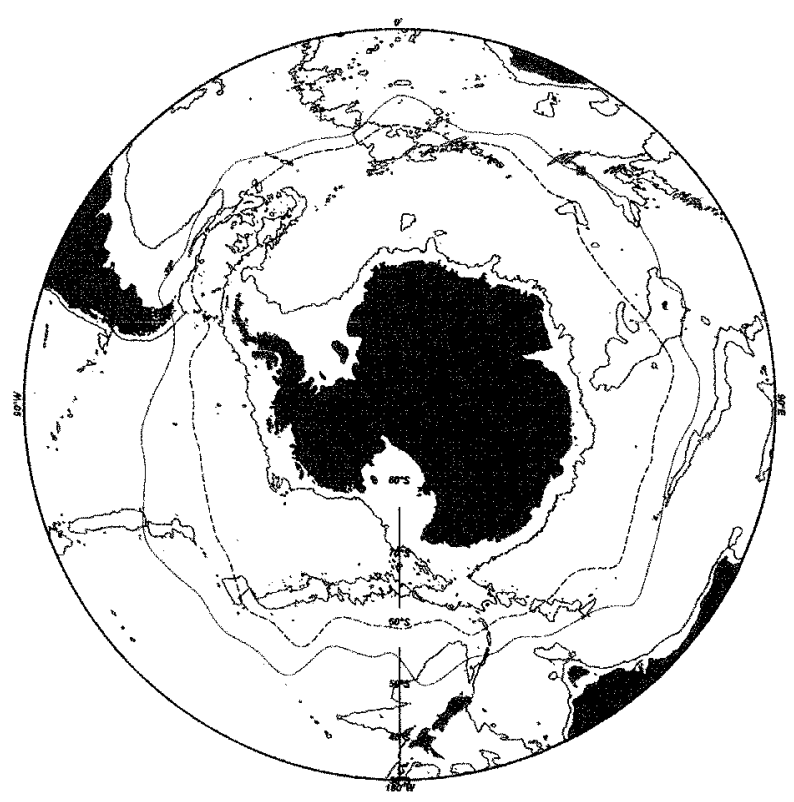

FIG. I - Map highlighting the mean position of the subsurface expression of the Sub-Antarctic Front $\left(6^{\circ} \mathrm{C}\right.$ at 200 m) and Antarctic Polar Front $\left(2^{\circ} \mathrm{C}\right.$ at $\left.200 \mathrm{~m}\right)$. The location of the Prince Edward Islands can be seen by the red square at approximately $47^{\circ} \mathrm{S}, 38^{\circ} \mathrm{E}$. 
Straddled between the northern and southern boundaries of the ACC, sub-Antarctic islands are typically oceanic; experiencing moist, cool and windy climates. They are classified as regions in which the terrestrial and marine ecosystems are relatively simple and extremely sensitive to perturbations. This paper focuses on the Prince Edward Islands as a case study to highlight the influence changes in climate conditions have on the marine ecosystem. Lying directly within the ACC, these islands provide an ideal ecological laboratory for studying how shifts in atmospheric and oceanic circulation patterns in the Indian sector of the Southern Ocean will increase the ease with which these islands and their ocean surrounds can be invaded by alien species (Smith 2002).

\section{THE PRINCE EDWARD ISLANDS}

The Prince Edward Islands are located in the Indian sector of the Southern Ocean at approximately $46^{\circ} 50^{\prime \prime} S$ and $37^{\circ} 50^{\prime \prime} \mathrm{E}$. The nearest landfall is the Crozet Island Group $950 \mathrm{~km}$ to the east, while South Africa lies over $2000 \mathrm{~km}$ to the northwest. Extensive oceanographic surveys have shown that the Prince Edward Islands are sandwiched between the SAF to the north and the Antarctic Polar Front (APF) to the south (Ansorge \& Lutjeharms 2002). These fronts separate warm Sub-Antarctic Surface Water (SASW) from cooler Antarctic Surface Water (AASW), with a zone of transition known as the Antarctic Polar Frontal Zone (APFZ) between the two. The SAF and APF demonstrate a high degree of latitudinal variability in this region (fig. 2) and it is thought that the complexity of the ACC in the vicinity of these islands (Ansorge \& Lutjeharms
2003) results in an increase in the interchange of Antarctic and sub-Antarctic surface and intermediate water masses (Deacon 1982). Indeed, recent investigations (Ansorge \& Lutjeharms 2003, Bernard et al. 2007) have identified the region upstream of the Prince Edward Islands as an "eddy corridor" in which eddies formed by the ACC interaction with the shallow southwest Indian Ridge transport physical and biological properties typical of the Antarctic northwards into the island vicinity.

\section{CLIMATE IMPLICATIONS - A THROUGH-FLOW SYSTEM?}

The Prince Edward Islands are seasonally characterised by dense populations of top predators (Hänel \& Chown 1998) and subsequently any changes in the frontal dynamics, either in the vicinity of these islands or further afield, may have strong implications on their foraging behaviour. Changes in the intensity and geographic position within these frontal systems are likely to coincide with dramatic changes in the distribution of species and total productivity within the Southern Ocean. It is expected that latitudinal shifts in the positions of oceanic fronts may be coupled to atmospheric changes and will become more dramatic and frequent in response to global climate change.

There is growing evidence that the geographical position of the SAF in the proximity of the Prince Edward Islands plays an important role in forming local macro- and mesoscale oceanographic conditions (Pakhomov et al. 2000a, Ansorge \& Lutjeharms 2002). Previous investigations have shown that when the SAF lies far north of the islands, the interaction between the ACC and the island group results

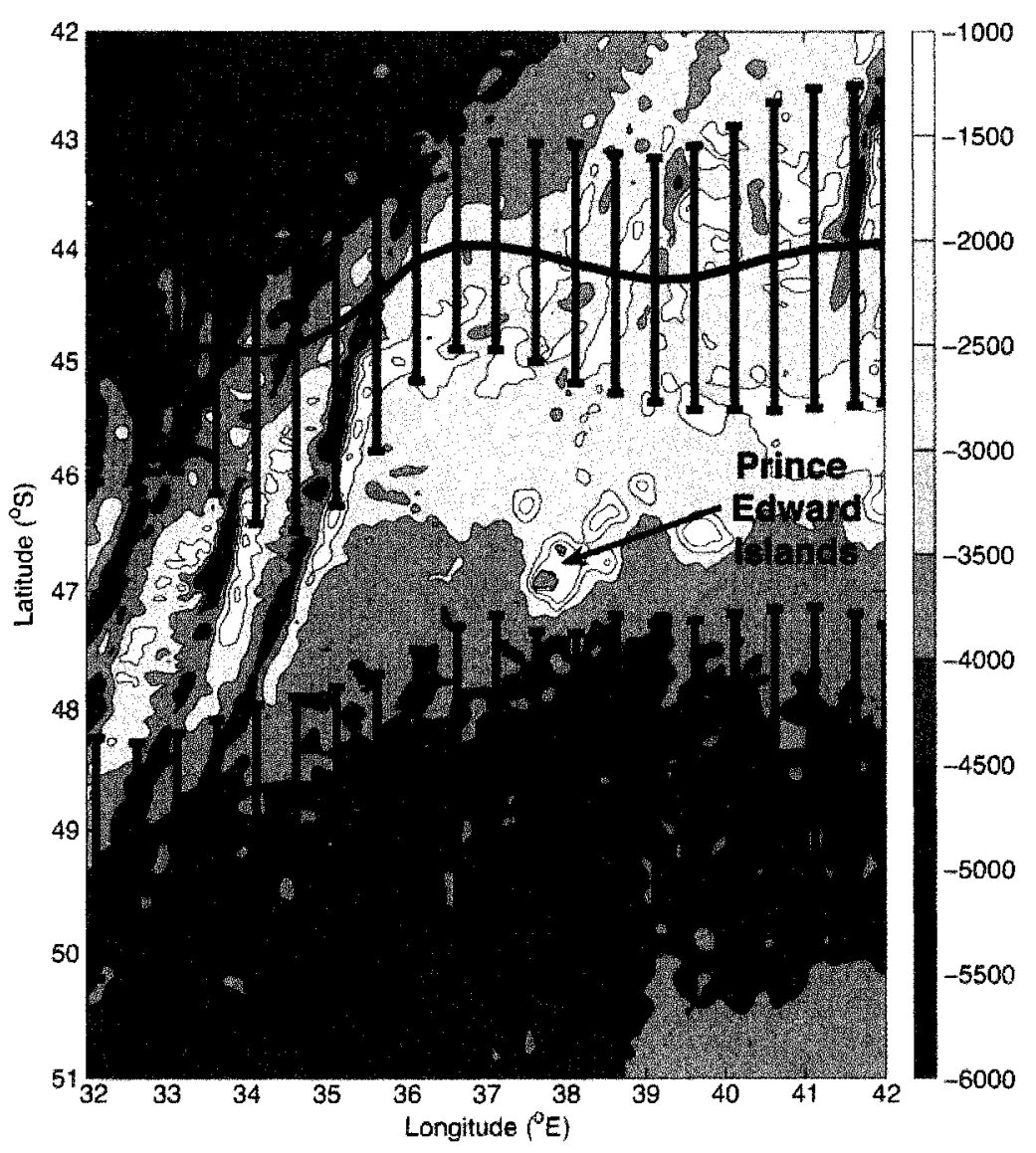

FIG. 2 - Average surface position of the Sub-Antarctic $\left(8^{\circ} \mathrm{C}\right)$ and Antarctic Polar $\left(4^{\circ} \mathrm{C}\right)$ fronts derived from a five-year Advanced Microwave Scanning Radiometer - Earth Observing System dataset (AMSR-E) (shown in a black line) with respect to the Prince Edward Island group. The error bars indicate the extent of the respective fronts within one standard deviation. Bottom topography is also shown in metres. 
in water retention over the inter-island region encouraging algal bloom development (Perissinotto \& Duncombe Rae 1990). During these periods, signature Antarctic species along with many typical APFZ species, suggest that water typical of modified Antarctic Surface Water dominates this region. In contrast, when the SAF meanders southwards and thus in closer proximity to the islands, advection forces prevail and a flow-through system rich in both sub-Antarctic and subtropical species is established between the islands (Pakhomov et al. 2000b). Historical data from over 30 crossings of the SAF in the upstream region of the island group between 1959 and 1999 indicate a possible gradual southward migration in the geographic position of this front but are not conclusive (Pakhomov \& Chown 2003) (fig. 3a). Nevertheless, less frequent subsurface observations in the upstream region of the Prince Edward Islands also confirm a southward shift in the SAF position (fig. 3b).

The most direct effect of a meridional shift in the SAF can be seen from changes within the species composition of the zooplankton. A review of their composition around the Prince Edward Islands indicates that over the past two decades the contribution of Antarctic species decreased by approximately $20 \%$, whereas the number of subtropical species found in the areas had increased from 6\% to 26\%. This is also supported by accidental catches of subtropical fish species during the long-line fishery in the proximity of these islands ( $\mathrm{Nel}$ pers. comm.). Although a shortterm variability and eddy transport cannot be completely discounted, it may be postulated that warmer-water species have intruded into the APFZ more frequently during the past decades (fig. 4). Furthermore, it has been suggested that a southward shift in the position of the SAF would favour a through-flow regime over the island region and thus prevent bloom events from occurring (Pakhomov \&
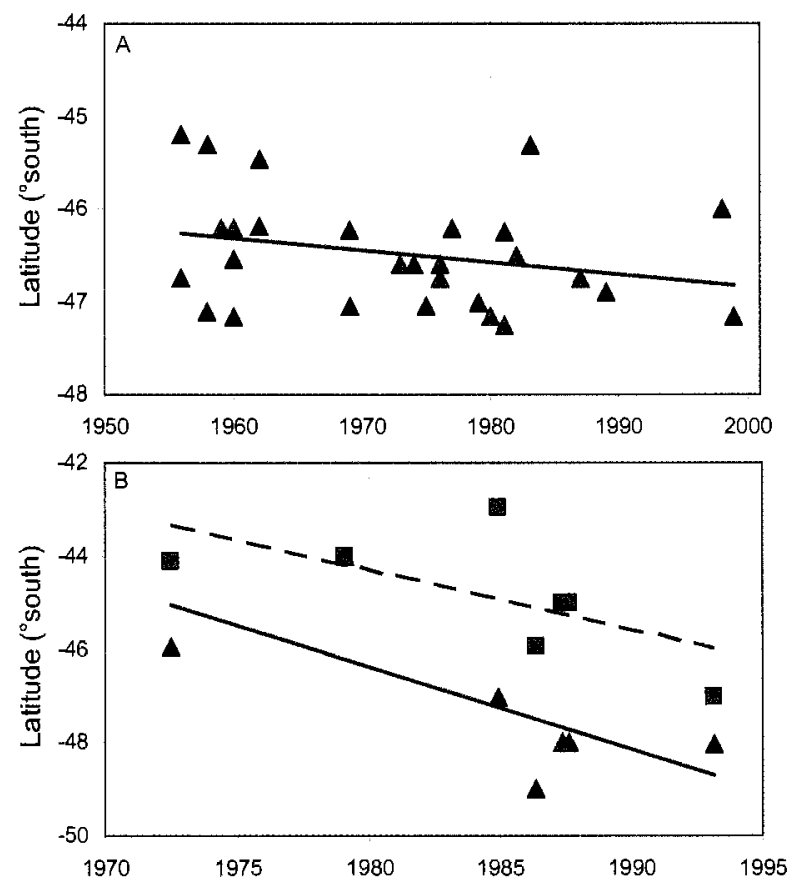

FIG. 3 - (A) Surface position of the Sub-Antarctic Front since 1955 (modified from Pakhomov \& Chown 2003). (B) Subsurface expression of the Sub-Antartic Front since 1972 in salinity (red squares) and temperature (blue triangles) (modified from Gille 2002).
Chown 2003). Indeed, a decline in stable isotope carbon values of a bottom dwelling shrimp, Nanticaris marionis, indirectly postulates a decrease in the occurrence of bloom conditions in the inter-island region between the $1980 \mathrm{~s}$ and 2000s (Pakhomov et al. 2004). Lastly, a decrease in chlorophyll concentrations near the islands since 1976 provides further support that a variation in the position of the SAF has occurred during the past 30 years (Pakhomov \& Chown 2003).

\section{CONCLUSION}

Global climate change is expected to have substantial effects in polar ecosystems (Barnett et al. 2001). The study of relatively simple and ecologically sensitive systems such as the sub-Antarctic islands and their surrounding waters may be particularly useful for identifying clear responses to such changes (Bergstrom \& Chown 1999). Physical data confirm that the mean sea surface temperatures at the Prince Edward Islands have increased by $>1{ }^{\circ} \mathrm{C}$ over the past 60 years (Melice et al. 2003). Mirroring this is a decrease of nearly $500 \mathrm{~mm}$ in precipitation, an increase of over 200 hours in sunshine and an increase in winds from the warmer sector in the Northwest (Rouault et al. 2005). It is unclear whether this change is expected to continue and at what rate. However, it may have already promoted long-term changes in landbased top predator populations at the islands (Crawford et al. 1998), possibly, through food-chain modifications (Pakhomov et al. 2004).

What is clear is that the entire sub-Antarctic system is in a state of flux. However, it is essential to differentiate between natural background variability and long-term trends driven by extrinsic forces such as climate change (Pakhomov \& Chown 2003). Long-term research on the ocean environment of sub-Antarctic islands and in particular the Prince Edward Islands is critical if the mechanisms needed to sustain high concentrations of marine life in a changing environment are to be better understood and a unique component of the planet's biological diversity is to be conserved.

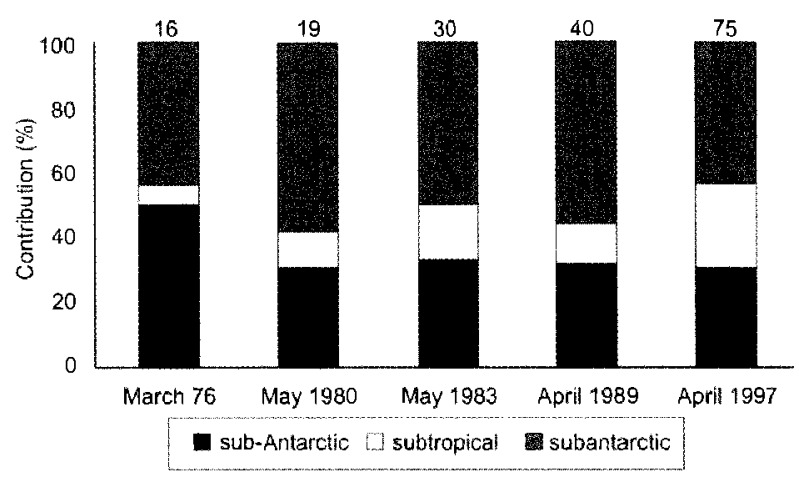

FIG. 4 -Long-term changes in the composition of zooplankton species in the vicinity of the Prince Edward Islands since March 1976 (modified from Pakhomov et al. 2000b). 


\section{REFERENCES}

Ansorge, I.J. \& Lutjeharms, J.R.E. 2002: The hydrography and dynamics of the ocean environment of the Prince Edward Islands. Joumal of Marine Systems 37: 107-127.

Ansorge, I.J. \& Lutjeharms, J.R.E. 2003: Eddies originating from the South-West Indian Ridge. Joumal of Marine Systems 39: 1-18.

Barnett, T.P., Pierce, D.W., AchutaRao, K.M., Gleckler, P.J., Santer, B.D., Gregory, J.M. \& Washington, W.M. 2001: Penetration of human-induced warming into the World's oceans. Science 309: 284-287.

Bergstrom, D.M. \& Chown, S.L. 1999: Life at the front: history, ecology and change on southern ocean islands. Trends in Ecology and Evolution 14: 472-477.

Bernard, A.T.F., Ansorge, I.J., Froneman, P.W., Lutjeharms, J.R.E., Bernard K.S. \& Swart, N. 2007: Entrainment of Antarctic euphausiids across the Antarctic Polar Front by a cold eddy. Deep-Sea Research I: Oceanographic Research Papers 54: 1841-1851.

Crawford, R.J.M., Hurford, J., Greyling, M. \& Nel, D.C. 1998: Population size and trends of some seabirds at Marion Island. New Zealand Natural Science 23: 42.

Deacon, G.E.R. 1982: Physical and biological zonation in the Southern Ocean. Deep-Sea Research 29: 1-15.

Fyfe, J.C. \& Saenko, O.A. 2006: Southern Ocean changes due to human influence. Newsletter for the Canadian Antarctic Research Network 22: 5-6.

Gille, S.T. 2002: Warming of the Southern Ocean since the 1950s. Science 295: 1275-1277.

Gordon, A.L. 1986: Interocean exchange of thermocline water. Journal of Geophysical Research 91: 5037-5046.

Hänel, C. \& Chown, S.L. 1998: An Introductory Guide to the Marion and Prince Edward Island Special Nature Reserves 50 Years after Annexation. Department of Environmental Affairs and Tourism, Pretoria.

Lutjeharms, J.R.E. 1985: Location of frontal systems between Africa and Antarctica: some preliminary results. Deep-Sea
Research 32: 1499-1509.

McCartney, M.S. 1982: The subtropical recirculation of Mode Waters. Deep-Sea Research 40: 427-464.

Mélice, J.L., Lutjeharms, J.R.E., Rouault, M. \& Ansorge, I.J. 2003: Sea-surface temperatures at the sub-Antarctic islands Marion and Gough during the past 50 years. South African Journal of Sicience 99: 363-366.

Oke, P.R. \& England, M.H. 2004: Oceanic response to changes in the latitude of the Southern Hemisphere subpolar westerly winds. Journal of Climate 17: 1040-1054.

Pakhomov, E.A., Ansorge, I.J \& Froneman, P.W. 2000a: Variability in the inter-island environment of the Prince Edward Islands (Southern Ocean). Polar Biology 23: 593-603.

Pakhomov, E.A., Froneman, P.W., Ansorge, I.J. \& Lutjeharms, J.R.E. 2000b: Temporal variability in the physicalbiological environment of the Prince Edward Islands (Southern Ocean). Journal of Marine Systems 26: 75-95.

Pakhomov, E.A. \& Chown, S.L. 2003: The Prince Edward Islands: Southern Ocean oasis. Ocean Yearbook, 17: University of Chicago Press, Chicago, USA: 348-379.

Pakhomov, E.A., McClelland, J.W., Bernard, K., Kaehler, S. \& Montoya, J.P. 2004: Spatial and temporal shifts in stable isotope values of bottom-dwelling shrimp Nauticaris marionis at the sub-Antarctic archipelago. Marine Biology 144: $317-325$

Perissinotto, R. \& Duncombe-Rae, C.M. 1990: Occurrence of anticyclonic eddies on the Prince Edward Plateau (Southern Ocean): effects on phytoplankton biomass and production. Deep-Sea Research 37: 777-793.

Rouault, M., Mélice, J.-L., Reason, C.J.C. \& Lutjeharms, J.R.E. 2005: Climate variability at Marion Island, Southern Ocean since 1960. Journal of Geophysical Research 110: C05007 9 pp.

Smith, V. 2002: Climate change in the sub-Antarctic: An illustration from Marion Island. Climatic Change 52: 345-357.

Speich, S., Blanke, B. \& Madec, G. 2001: Warm and cold water paths of a GCM thermohaline conveyor belt. Geophysical Research Letters 28: 311-314.

(accepted 6 October 2009) 